ARTICLE OPEN

\title{
A simple method for the inhibition of the corrosion of carbon steel by molten nitrate salt for thermal storage in concentrating solar power applications
}

\author{
Yaroslav Grosu (D) ${ }^{1}$, Udayashankar Nithiyanantham ${ }^{1}$, Abdelali Zaki ${ }^{1}$ and Abdessamad Faik ${ }^{1}$
}

\begin{abstract}
Corrosion is an important issue in high-temperature applications such as Concentrated Solar Power (CSP) technology, playing a crucial role in the long-term use of storage tanks, heat exchanger and piping materials which account for a considerable component of the investment costs. While there are many studies regarding the corrosion rates of container materials under the conditions of CSP, there is little progress in the field of their degradation prevention by anticorrosion methods. This work presents an analysis of the corrosion mechanisms between the most economical construction material—carbon steel-and molten nitrate salt. A method to protect the carbon steel against corrosion by molten salt at high temperature was proposed, involving the formation of a calcium carbonate layer on the carbon steel surface. The stability of the layer was tested under isothermal and temperature cycling conditions up to $500^{\circ} \mathrm{C}$, in both inert and air atmospheres in the presence or absence of humidity. The protection method proposed has potential to reduce investment costs for CSP technology.
\end{abstract}

npj Materials Degradation (2018)2:34; doi:10.1038/s41529-018-0055-0

\section{INTRODUCTION}

The durability of materials is particularly important for hightemperature applications like Concentrated Solar Power (CSP) technology. ${ }^{1,2}$ CSP is a renewable energy technology, which aims to utilize thermal energy for electricity production by concentrating solar irradiation on a working body. ${ }^{3-6}$ The absorbed heat is then used for electricity production using classical power cycles. One of the most important competitive advantages of CSP is its dispatchability (ability to produce electricity on demand) thanks to the relatively simple storage technology-Thermal Energy Storage (TES). ${ }^{1,2}$ This can be achieved by heating a large amount of storage material held in a storage tanks. Typically, thousands of tons of molten salts are used. For example, the mass of salts at GEMASOLAR CSP plant is 8500 tons (ref. ${ }^{7}$ ), at Andasol-1 CSP plant it is 28500 tons (ref. ${ }^{8}$ ) and at Solana CSP plant it is 125000 tons (http://www.abengoasolar.com, ref. ${ }^{9}$ ). The heat stored in the molten salt is transferred, when needed, to the power block by a heat exchanger. In some CSP plants, the same molten salt is used as the heat transfer fluid in the solar field. ${ }^{7,10}$ Currently, the investment costs for CSP are high due to the cost of construction materials for storage tanks, heat exchanger, pipes and receiver. The initial investment costs are a large contribution to the final price of produced electricity. This affects the competitiveness of this renewable technology in the market. In this context, numerous studies have explored the corrosion behaviour of potential construction materials with different storage media or heat transfer fluids. ${ }^{1-30}$

Molten nitrate salt, known as Solar Salt, is the most technologically mature solution for CSP. It consists of $60 \mathrm{wt} \%$ $\mathrm{NaNO}_{3}-40 \mathrm{wt} \% \mathrm{KNO}_{3}$. Corrosion studies of solar salt go back to 1985 where Slusser et al. tested several nickel- and iron-based alloys. ${ }^{13}$ In this work, immersion tests were done at $510^{\circ} \mathrm{C}$ and $705^{\circ} \mathrm{C}$ followed by weight loss analysis. Slusser et al. found that the chromium content positively influenced the resistance of the alloys to corrosion. Particularly, the alloys with a chromium content of $15-20 \mathrm{wt} \%$ behaved better compared with iron alloys with lower chromium content, especially at higher temperatures. The study showed a drastic increase in corrosion damage at temperatures above $650^{\circ} \mathrm{C}$ for all the investigated alloys, which may be attributed to the decomposition of nitrate salt at higher temperature. More recent studies have been dedicated to the corrosion aspects of other nitrate salts like Hitec (53 wt\% $\mathrm{KNO}_{3}-40 \mathrm{wt} \% \mathrm{NaNO}_{2}-7 \mathrm{wt} \% \mathrm{NaNO}_{3}$ ) and HitecXL (42 wt\% $\mathrm{Ca}$ $\left.\left(\mathrm{NO}_{3}\right)_{2}-15 \mathrm{wt} \% \mathrm{NaNO}_{3}-43 \mathrm{wt} \% \mathrm{KNO}_{3}\right)$. Stainless steels such as AISI 304 and 430, a low-Cr alloy steel known as T22 and a carbon steel A1 were tested by Fernandez et al. ${ }^{14}$ The authors concluded that HitecXL salt is less corrosive compared with solar salt, demonstrating the positive effect of $\mathrm{Ca}\left(\mathrm{NO}_{3}\right)_{2}$ in a nitrate salt. Ruiz-Cabañas et al. ${ }^{15}$ investigated the corrosion behaviour of solar salt by means of in situ tests with carbon steel A516.Gr70. In this study, ${ }^{15}$ homogenous oxidation was recorded after immersion corrosion tests. In both studies, ${ }^{14,15}$ magnesium was present as an impurity in the salt and was incorporated into the corrosion layer. Hitec and solar salts were examined by Federsel et al. with several types of steel (1.4541 and 2.4816 steels with Hitec; 1.4541 and 1.4571 steels with solar salt) demonstrating that chlorides increase the corrosion rates. ${ }^{16}$ It was also shown in this work ${ }^{16}$ that an addition of a small amount of $\mathrm{Na}_{2} \mathrm{O}$ has increased the corrosion rates. A molten ternary salt composed of $\mathrm{LiNO}_{3}-\mathrm{NaNO}_{3}-\mathrm{KNO}_{3}$ was tested with five different steels (SB450, T22, T5, T9 and X20) revealing that corrosion resistance improves with increasing $\mathrm{Cr}$ content since it creates a protective layer of $(\mathrm{Fe}, \mathrm{Cr})_{3} \mathrm{O}_{4}$ (ref. $\left.{ }^{17}\right)$. It was found that $\mathrm{Li}$ absorbed into the corrosion scales due to the presence of

${ }^{1} \mathrm{CIC}$ Energigune, Albert Einstein 48, Miñano (Álava) 01510, Spain

Correspondence: Yaroslav Grosu (ygrosu@cicenergigune.com) or Abdessamad Faik (afaik@cicenergigune.com)

Received: 22 March 2018 Accepted: 10 October 2018

Published online: 31 October 2018 
$\mathrm{LiNO}_{3}$ in the molten salt. ${ }^{17}$ Goods and Bradshaw investigated the compatibility of stainless steels SS-304 and SS-316 at $570^{\circ} \mathrm{C}$ as well as carbon steel $\mathrm{A} 36$ at $316^{\circ} \mathrm{C}$ with several nitrate salts mixtures. ${ }^{18}$ In long immersion tests of about $7000 \mathrm{~h}$, the authors reported acceptable corrosion rates even in the presence of some impurities in the salt. ${ }^{18} \mathrm{~A}$ corrosion investigation for molten solar salt with SS-321 and SS-347 iron-based alloys and In625 (22\% $\mathrm{Cr}-8 \% \mathrm{Mo}-61 \% \mathrm{Ni}-5 \% \mathrm{Fe}-3 \% \mathrm{Nb})$ and $\mathrm{HA} 230(22 \% \mathrm{Cr}-1 \% \mathrm{Mo}-60 \%$ $\mathrm{Ni}-1 \% \mathrm{Fe}-14 \% \mathrm{~W}$ ) alloys was conducted by Sandia National Laboratories at different temperatures. ${ }^{19}$ In the aforementioned study, an increase of the corrosion rate was observed for all materials when the temperature was increased to $680^{\circ} \mathrm{C}^{19}$ Moreover, in this work, ${ }^{19}$ it was demonstrated that the corrosion mechanism changes with rising temperatures and the dissolution of $\mathrm{Cr}, \mathrm{Mo}$ and $\mathrm{W}$ in the molten salt take place above $600^{\circ} \mathrm{C}$. This resulted in a decreased corrosion rate for iron-based alloys when compared with nickel-based alloys at temperatures above $600{ }^{\circ} \mathrm{C}$, while nickel-based alloys performed better at lower temperatures. In a recent study, the effect of humidity, the initial state of the material and impurities in the salt were investigated for carbon steel and two stainless steels of 304 and 316 types in contact with molten HitecXL salt. ${ }^{20}$ The rates of corrosion increased for carbon steel with the presence of moisture in the salt, while corrosion rates for stainless steels were not considerably affected by the presence of moisture. ${ }^{20}$ Alumina and silica nanoparticle doping was demonstrated to increase the corrosion rates of molten HitecXL salt due to the excess of oxygen in the system from the air entrapped in the interparticle porosity ${ }^{12}$

The need to improve the efficiency of thermal to electrical energy transformation requires operating CSP technology at higher temperatures. In this regard, storage materials and heat transfer fluids with higher stability like carbonate or chloride salts are also considered as candidates. The ternary salt $\mathrm{Li}_{2} \mathrm{CO}_{3}-\mathrm{Na}_{2} \mathrm{CO}_{3}-\mathrm{K}_{2} \mathrm{CO}_{3}$ was investigated for compatibility with HR3C steel $(25 \% \mathrm{Cr}-20 \% \mathrm{Ni}-53 \% \mathrm{Fe})$, demonstrating that oxidation is the main corrosion mechanism. ${ }^{21}$ Hastelloy C-276 and C-22 and stainless steel 304 with chloride salts were studied at temperatures up to $900^{\circ} \mathrm{C}$ in the presence $e^{22,23}$ and absence ${ }^{23}$ of air. The authors concluded that the corrosion rates decrease with the absence of oxygen in the atmosphere. Different hastelloys have demonstrated a better corrosion resistance compared with stainless steel 304 . In ref. ${ }^{24}$ a new sensible TES material (a byproduct from potash industry) was tested for compatibility with A316 stainless steel. The by-products composition was predominately $\mathrm{NaCl}$. The corrosion rate was found to be around two times greater when compared with solar salt. These results are inagreement with other studies which show the negative effect of chlorides on the compatibility of construction materials, including the case of Solar salt. ${ }^{25}$ Stainless steel 316 was examined by Sarvghad et al. for compatibility with mixtures of $\left(\mathrm{NaCl}-\mathrm{Na}_{2} \mathrm{CO}_{3}\right)$ and $\left(\mathrm{NaCl}-\mathrm{Na}_{2} \mathrm{SO}_{4}\right)$ at $700{ }^{\circ} \mathrm{C}$ and $\left(\mathrm{Li}_{2} \mathrm{CO}_{3}-\mathrm{K}_{2} \mathrm{CO}_{3}-\mathrm{Na}_{2} \mathrm{CO}_{3}\right)$ at $450{ }^{\circ} \mathrm{C}$ (ref. ${ }^{31}$ ). Their analysis showed that intergranular attack of the steel occurred in case of $\left(\mathrm{NaCl}-\mathrm{Na}_{2} \mathrm{CO}_{3}\right)$ salt, while homogeneous oxidation of the stainless steel was reported when ternary carbonate salt was used.

The corrosion studies of some thermochemical (TCM) and Phase Change Materials (PCMs) with different construction materials can be found in ref. ${ }^{26-30}$. It can be generally noticed that stainless steels SS316 and SS304 are resistant to the corrosion by lowtemperature $\mathrm{PCMs} / \mathrm{TCMs}$, including Zinc nitrate hexahydrate, ${ }^{26}$ hydrogen phosphate dodecahydrate, ${ }^{26} \mathrm{Na}_{2} \mathrm{~S} / \mathrm{H}_{2} \mathrm{O}$ (ref. ${ }^{30}$ ) and others. ${ }^{27-29}$ While aluminium is often being corroded by those materials, ${ }^{26}$ demonstrating resistance to some commercial PCMs like $\mathrm{Na}_{2} \mathrm{SO}_{4}+\mathrm{H}_{2} \mathrm{O}$ and $\mathrm{MgSO}_{4} \cdot 7 \mathrm{H}_{2} \mathrm{O}$ (ref. ${ }^{27}$ ). Copper often demonstrates poor corrosion behaviour, particularly with $\mathrm{Na}_{2} \mathrm{~S}$ / $\mathrm{H}_{2} \mathrm{O}$ (ref. ${ }^{30}$ ), $\mathrm{CaCL}_{2}, \mathrm{Na}_{2} \mathrm{~S}, \mathrm{Ca}(\mathrm{OH})_{2}, \mathrm{MgCl}_{2}$ and $\mathrm{MgSO}_{4}$ (ref. ${ }^{29}$ ).

A review of the heat-transfer fluids which are used in CSP is found in ref. ${ }^{1}$ This includes liquids such as oils, molten salts and molten metals as well as their corrosion aspects with other materials used for containers.

According to the literature, it is evident that the most economically attractive material, namely carbon steel, cannot nominally sustain the harsh conditions of molten salt at high temperature. Such incompatibility is an obstacle in decreasing the levelized cost of electricity (LCOE) produced by CSP if such technology requires the use of costly or specialised construction materials.

Application of coatings is one of the most effective solutions to lower the cost of construction materials, ${ }^{32-36}$ however, the stability of these coatings at high temperatures is an issue. Some solutions which have been applied to water boilers, where the temperature can rise up to $550^{\circ} \mathrm{C}$, include thermal spraying, pad welding and cold spraying with corrosion resistive materials like $\mathrm{Al}$, high $\mathrm{Cr}$ content alloys with $\mathrm{Ni}$ or Fe matrix, $\mathrm{ZrO}_{2}, \mathrm{ZrO}_{2}+\mathrm{Y}_{2} \mathrm{O}_{3}, \mathrm{Al}_{2} \mathrm{O}_{3}$. ${ }^{32,33}$ In ref. ${ }^{34}$ an aluminized slurry was proposed to protect against corrosion by molten nitrate salt at high temperature. Particularly, ferritic-martensitic P91 (Cr9-Mo1) and stainless steel 304 were tested to demonstrate the improved compatibility. ${ }^{34}$ In ref. ${ }^{35}$, the Inconel 738-LC was tested for corrosion with $45 \mathrm{wt} \% \mathrm{Na}_{2} \mathrm{SO}_{4}+$ 55 wt $\% \mathrm{~V}_{2} \mathrm{O}_{5}$ molten salt at $910{ }^{\circ} \mathrm{C}$. This coating was reported to have failed due to the formation of a mixed-oxide layer even though the material was sprayed with a NiCrAlY bond coat, a nanostructured scandia (3.6 mol\%), yttria $(0.4 \mathrm{~mol} \%)$ and costabilized zirconia (4SYSZ) topcoat by air plasma spraying (APS). TP347H coated with Hastelloy $\mathrm{C} 22$ ( $\mathrm{Ni}-\mathrm{Cr}-\mathrm{Mo}$ ) using a laser cladding technique was tested for compatibility with chloride salts $(\mathrm{KCl}$ and $\mathrm{NaCl})$ at temperatures up to $750^{\circ} \mathrm{C}^{36}$ This coating considerably improved the corrosion resistance. ${ }^{36}$ An Al slurry coating was recently proposed and demonstrated to be effective against molten nitrate and carbonate salts corrosion at $580^{\circ} \mathrm{C}$ and $650{ }^{\circ} \mathrm{C}$, respectively..$^{37}$

From the literature review, it can be deduced that the main mechanism for construction materials degradation is oxidation, if the maximum temperature is below the molten salt decomposition. The two main strategies to improve the compatibility of construction materials with molten salts are: (i) The use of metal alloys with high content of $\mathrm{Cr}$ and/or $\mathrm{Ni}$; and (ii) the use of stable anticorrosion coatings. Considering that investment costs for CSP technology play a critical role, new reliable methods for anticorrosion protection are specific targets.

In this work, we propose a new simple spray-coating method for improving the corrosion resistance of carbon steel against molten nitrate salt attack, expanding its lifetime and operational temperature range, particularly for CSP technology.

\section{RESULTS AND DISCUSSION}

Isothermal corrosion tests

Isothermal corrosion tests for carbon steel A516.Gr70, unexposed to the graphite layer (non-graphitized), with hydrated HitecXL' $\mathrm{H}_{2} \mathrm{O}$ salt produced a corrosion layer, which was observed by SEM crosssection analysis (Fig. 1a, b). XRD analysis of the samples surface showed that the layer is composed of iron oxides in the magnetite and haematite phases (Figure S3). On the other hand, the SEM analysis shows the formation of a protective layer on the surface of the carbon steel, which is an iron carbonate layer as discussed in our previous work. ${ }^{20}$ These layer is expected to be protective. ${ }^{38-}$

When the carbonate layer separates from the carbon steel, the oxidation thickness is observed to be around $1.0 \mu \mathrm{m}$ (Fig. 1a). However, when the carbonate layer remains attached, the oxidation thickness is around $0.6 \mu \mathrm{m}$ (Fig. 1b). Hence the presence of a carbonate layer reduces the amount of oxidation by nearly twofold. Though, the case shown in Fig. $1 \mathrm{~b}$ was rarely detected while statistically examining the carbon steel samples after the 

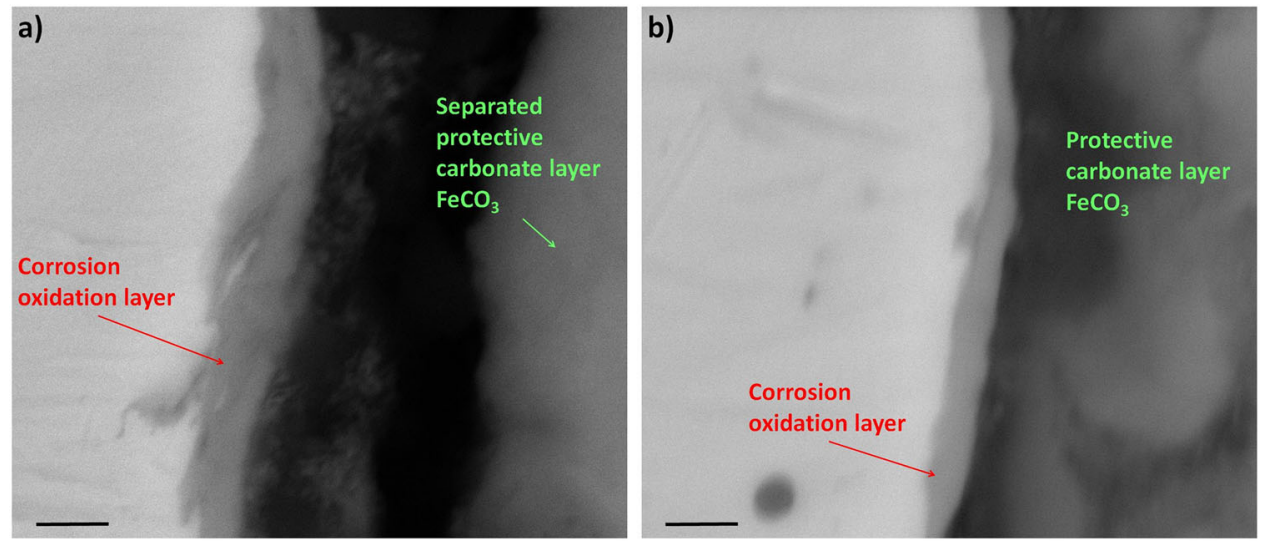

Fig. 1 SEM images of cross-sections of carbon steel after $1500 \mathrm{~h}$ corrosion test with HitecXL· $\mathrm{H}_{2} \mathrm{O}$. The cases of $\mathbf{a}$ separated and $\mathbf{b}$ attached protective $\mathrm{FeCO}_{3}$ layer. Scale bars are $1 \mu \mathrm{m}$
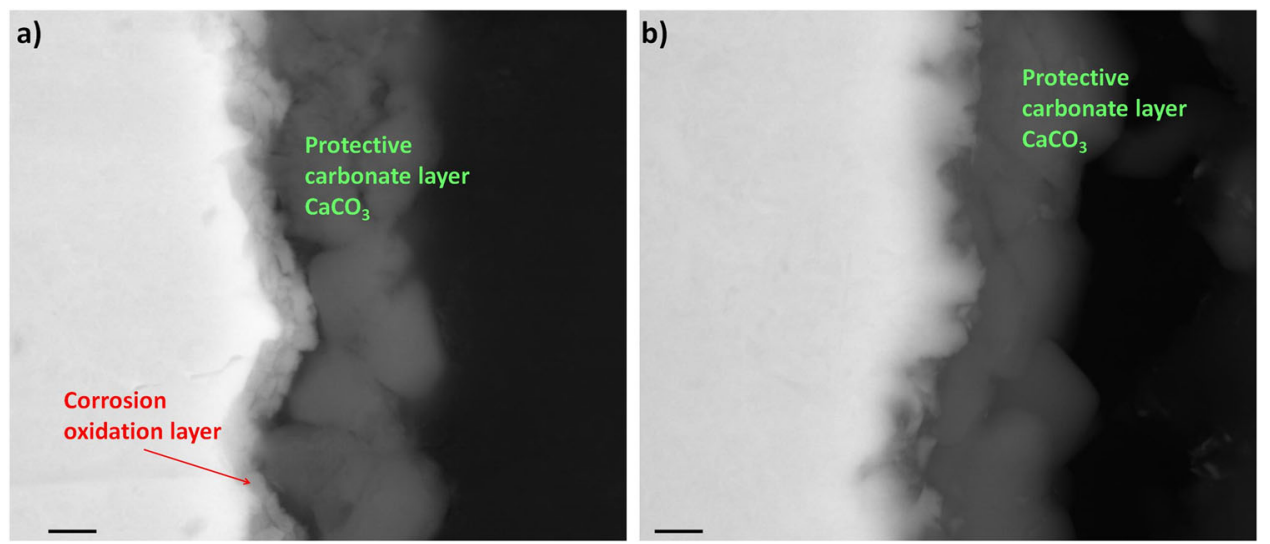

Fig. 2 SEM images of cross-sections of carbon steel after $1500 \mathrm{~h}$ corrosion test with $\mathrm{Hite} \mathrm{XL} \cdot \mathrm{H}_{2} \mathrm{O}+2 \mathrm{wt} \%$ Graphite. The cases of a presence and $\mathbf{b}$ absence of oxidation layer under $\mathrm{CaCO}_{3}$ carbonate layer. Scale bars are $1 \mu \mathrm{m}$

corrosion tests, and it was estimated that less than $1 \%$ of the surface was covered with $\mathrm{FeCO}_{3}$.

While being inspired by the protective properties of this carbonate layer, we decided to increase its formation during the corrosion test. In particular, the carbon concentration in the system was increased. To achieve this, graphite was added up to a total mass of $2 \mathrm{wt} \%$ into the salt prior to the corrosion tests (see section 'Salts preparation' for details). The isothermal corrosion tests revealed an unexpected and intriguing result. A dense firmly attached layer of calcium carbonate was formed on the surface of carbon steel (Fig. 2a, b). The formation of calcium carbonate was confirmed using XRD analysis with the spectra presented in Figure S3. The layer demonstrates the desired protective behaviour, by completely inhibiting the formation of the oxide layer (Fig. 2b). Only in a few rare zones, the corrosion layer was found on the steel surface. However, the thickness of the corrosion layer was reduced (Fig. 2a) when compared with the carbon steel without the graphite exposure (Fig. 1a). The same observations were seen on the surface of the carbon steel after the corrosion tests by SEMEDX (Fig. 3). In this case, the surface of carbon steel is covered by the cubic crystals of calcium carbonate in contrast to carbon steel which was not exposed to graphite. There are some spots on the carbon steel surface, which present a much lower concentration of carbon and a higher concentration of oxygen, suggesting the presence of oxides. XRD analysis confirmed the presence of a mixture of $\mathrm{CaCO}_{3}$ and iron oxide phases (Figure S3).
The obtained results illustrate the possibility of increasing the compatibility between carbon steel and molten HitecXL salt by raising the carbon concentration in the system. However, direct addition of graphite into the salt can cause a problem with the thermal decomposition of the unconsumed graphite at a higher temperature. The last point is demonstrated in Figure S5, where HitecXL' $\mathrm{H}_{2} \mathrm{O}$ salt with $2 \mathrm{wt} \%$ graphite shows a behaviour like pure HitecXL only until $450^{\circ} \mathrm{C}$. Nevertheless, the further increase of the temperature drives the decomposition process resulting with a pronounced mass loss at $\sim 450^{\circ} \mathrm{C}$.

These experiments provide important information on the corrosion process of carbon steel in molten nitrate salts and build a strong basis for the improvement of corrosion resistance method. The accumulated knowledge was used to develop more application-suitable anticorrosion methods. In particular, a simple method of spraying the carbon steel surface with a very thin layer of graphite was tested (see section 'Carbon steel samples preparation' for more details on sample preparation). In this case, the mass of graphite in the system is very low $-\sim 5 \cdot 10^{-3} \mathrm{~g} \cdot \mathrm{cm}^{-2}$ of graphite per area of carbon steel. This corresponds to about $0.08 \mathrm{wt} \%$ of graphite in the salt.

The results of the corrosion test for the graphite-treated (graphitized) carbon steel are summarized in Fig. 4. It was found that almost $99.9 \%$ of the surface is completely covered by the crystals of calcium carbonate. Only few spots exhibit lower concentration of crystals (Fig. 4b). The complete coverage of the carbon steel surface by the protective layer is mostly due to the 

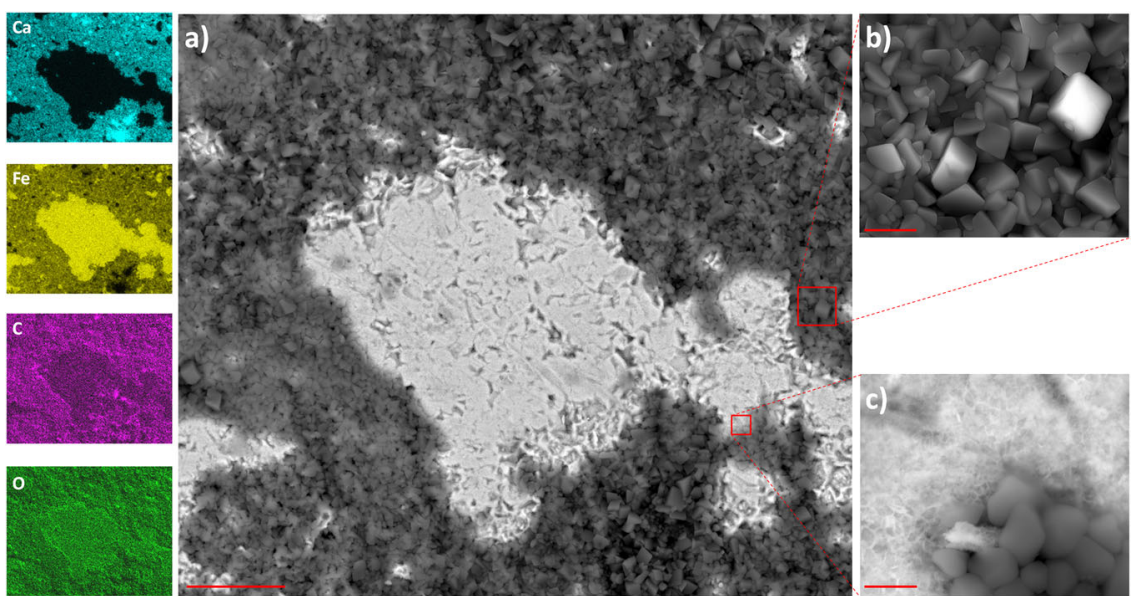

Fig. 3 SEM images and EDX mapping of the surface of carbon steel after $1500 \mathrm{~h}$ corrosion test with HitecXL. $\mathrm{H}_{2} \mathrm{O}+2 \mathrm{wt} \%$ graphite under different magnifications. Scale bar is a $25 \mu \mathrm{m}$, b $5 \mu \mathrm{m}$ and c $2 \mu \mathrm{m}$
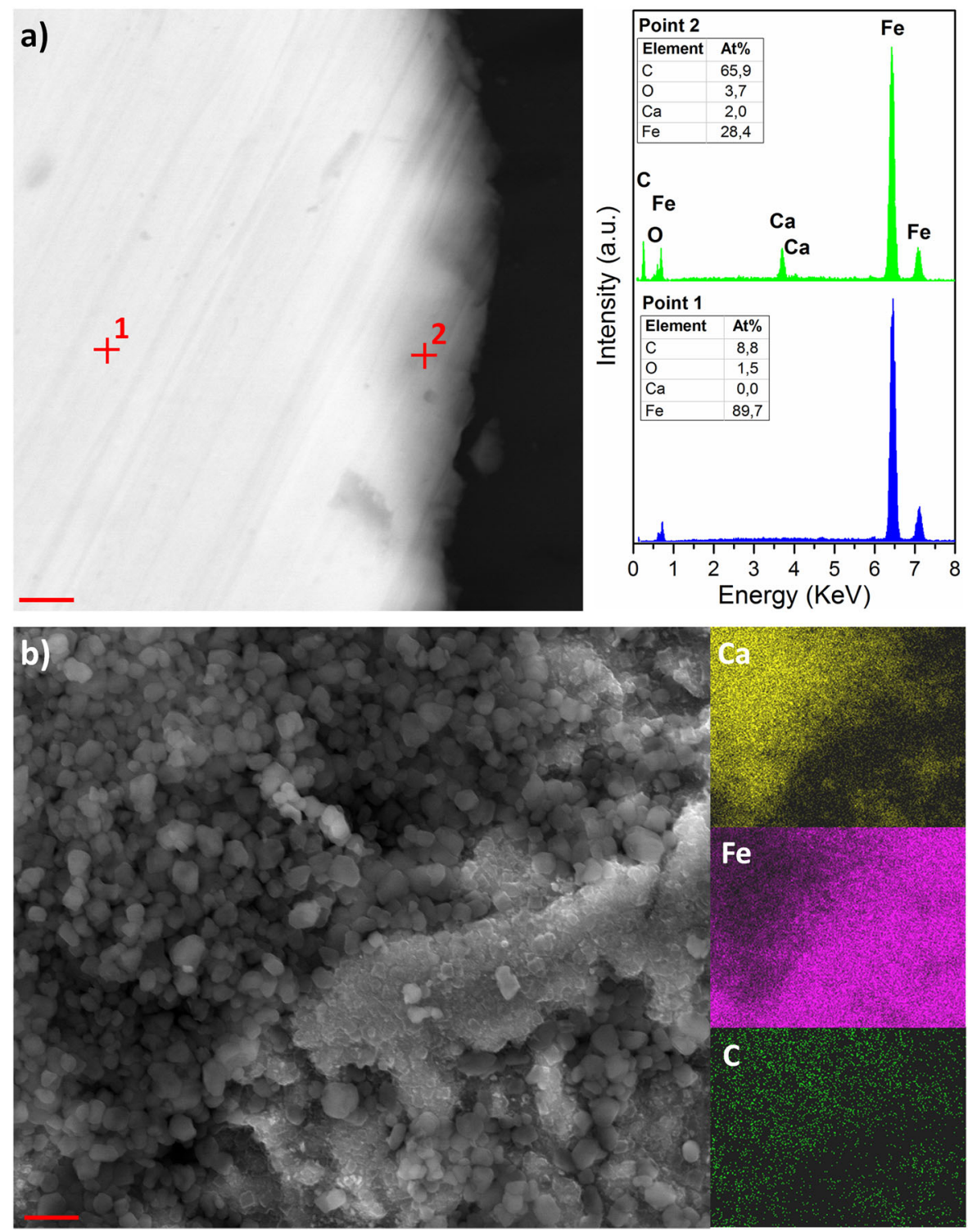

Fig. 4 SEM images and EDX mapping of a cross-section (scale bar is $1 \mu \mathrm{m}$ ) and $\mathbf{b}$ surface of graphitized carbon steel after $1500 \mathrm{~h}$ corrosion test with HitecXL· $\mathrm{H}_{2} \mathrm{O}$ (scale bar is $2 \mu \mathrm{m}$ ) 
Table 1. Corrosion rates of carbon steel under different conditions

\begin{tabular}{|c|c|c|}
\hline Conditions & System & Corrosion rate, $\mu \mathrm{m} /$ year \\
\hline & Carbon steel + HitecXL· $\mathrm{H}_{2} \mathrm{O}+2$ wt $\%$ Graphite & $3.2 \pm 0.5$ \\
\hline \multirow[t]{2}{*}{ Cycling, $300-500^{\circ} \mathrm{C}$, air, 125 cycles } & Carbon steel + HitecXL & $31.5 \pm 1.6$ \\
\hline & Graphitized carbon steel + HitecXL & $11.4 \pm 1.2$ \\
\hline
\end{tabular}
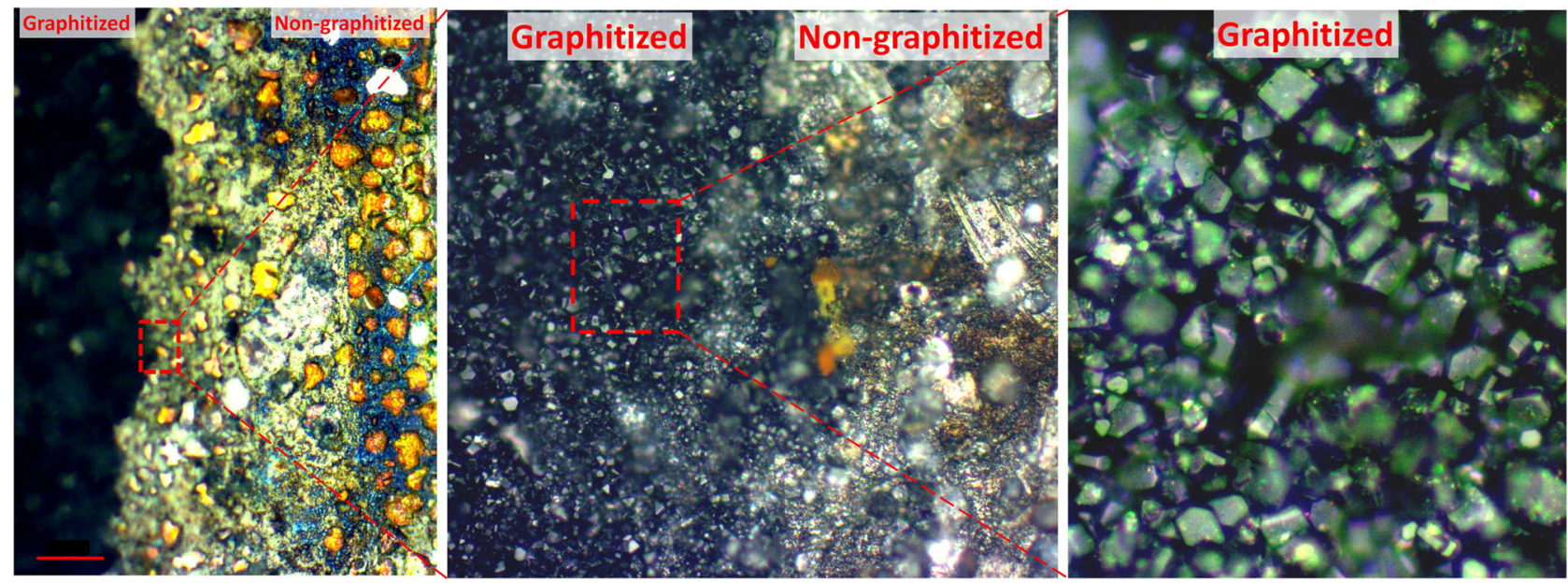

Fig. 5 Optical microscope images of the surface of partially graphitized carbon steel after $24 \mathrm{~h}$ corrosion test with HitecXL. Scale bar is $50 \mu \mathrm{m}$

initial homogenous distribution of graphite (Figure S11). The analysis of the cross-section revealed the absence of detectable corrosion layer and a very thin layer of $\mathrm{CaCO}_{3}$ on the surface, which is confirmed by EDX (Fig. 4a) and XRD (Figure S3) analyses. This result confirms the protective activity of $\mathrm{CaCO}_{3}$. The thermogravimetric curve of the salt after the corrosion test with graphitized carbon steel showed a decomposition temperature like the pure HitecXL (Figure S5). XRD analysis of these samples could barely detect the residual amount of iron oxides (much lower when compared with $2 \mathrm{wt} \%$ graphite case) and showed a clear peak of $\mathrm{CaCO}_{3}$ (Figure S3). The corrosion rates obtained for the experiments presented above are summarized in Table 1.

Other methods for creating the carbonate layer were tested in this work: (1) graphite doping of the salt to a concentration of $1 \mathrm{wt}$ $\%$; (2) ethanol-deposition of graphite onto the surface of carbon steel; (3) temperature pre-treatment under $\mathrm{CO}_{2}$ atmosphere and (4) $\mathrm{MgCO}_{3}$ doping of the salt. Details on the results of these experiments are presented in the Supplementary information (Figures S6-S10). For all the methods except for $\mathrm{MgCO}_{3}$ doping, the formation of $\mathrm{CaCO}_{3}$ protective layer was observed, however, complete coverage of the surface of carbon steel was not achieved.

Effect of oxygen and thermal cycling

Reactions which form the carbonate surface layer and the oxidation reactions on the carbon steel are competitive reactions. ${ }^{38-41}$ Thus additional corrosion test for the proposed method was performed under an air atmosphere to observe the formation of carbonate layer under more challenging conditions.

First, for demonstration purposes, half of the piece of carbon steel was sprayed with graphite, while the other half was not treated. After a $24 \mathrm{~h}$ corrosion test with HitecXL at $310^{\circ} \mathrm{C}$ under an air atmosphere, crystals of $\mathrm{CaCO}_{3}$ appeared and were observed under an optical microscope (Fig. 5). The line of separation between graphitized and non-graphitized surfaces is very clear (Fig. 5): while the graphitized part is well protected by $\mathrm{CaCO}_{3}$, the non-graphitized one exhibits clear signs of oxidation. XRD and SEM-EDX analyses further confirmed the formation of crystal $\mathrm{CaCO}_{3}$.

Given the excellent results under an air atmosphere, we decided to try more challenging conditions by performing thermal cycling in the range of $300-500{ }^{\circ} \mathrm{C}$ with exposure to air, which is the typical condition for a CSP plant. The experiment consisted of 125 consecutive cycles over a $500 \mathrm{~h}$ period, the results of these tests are seen in Fig. 6 . In the case of non-graphitized carbon steel, the corrosion layer thickness is high and layer detachment is observed (Fig. 6a). While the increased rate of oxidation can be attributed to a higher maximum temperature in the cycling test compared with isothermal at $310^{\circ} \mathrm{C}$, the layering of the material is probably due to thermal cycling and is caused by different dilatation of oxide layer and carbon steel. On the other hand, graphitized samples clearly demonstrate the formation of a layer of $\mathrm{CaCO}_{3}$ crystal over the entire surface (Fig. 6b), with little evidence of the oxidation. XRD analysis reveals the presence of $\mathrm{CaCO}_{3}$ phase and two iron oxides-magnetite and haematite (Figure S4). This suggests that some oxides form during the corrosion test, however, the corrosion rate decrease about three times compared with non-graphitized carbon steel (Table 1).

The results demonstrate the potential of a simple graphitization method to improve the corrosion resistance of carbon steel against molten nitrate salts. The final evaluation, however, requires further corrosion tests by using experimental conditions close to real conditions. In particular, it is necessary to verify the stability of the formed carbonate layer under flow conditions. It must be noted that the presence of graphite on the surface of carbon steel is also beneficial in terms of lowering the surface energy of the carbon steel, which is observed from the contact angle images of the molten salt (Figure S12). This property is beneficial for molten salt pumping under harsh conditions. It 

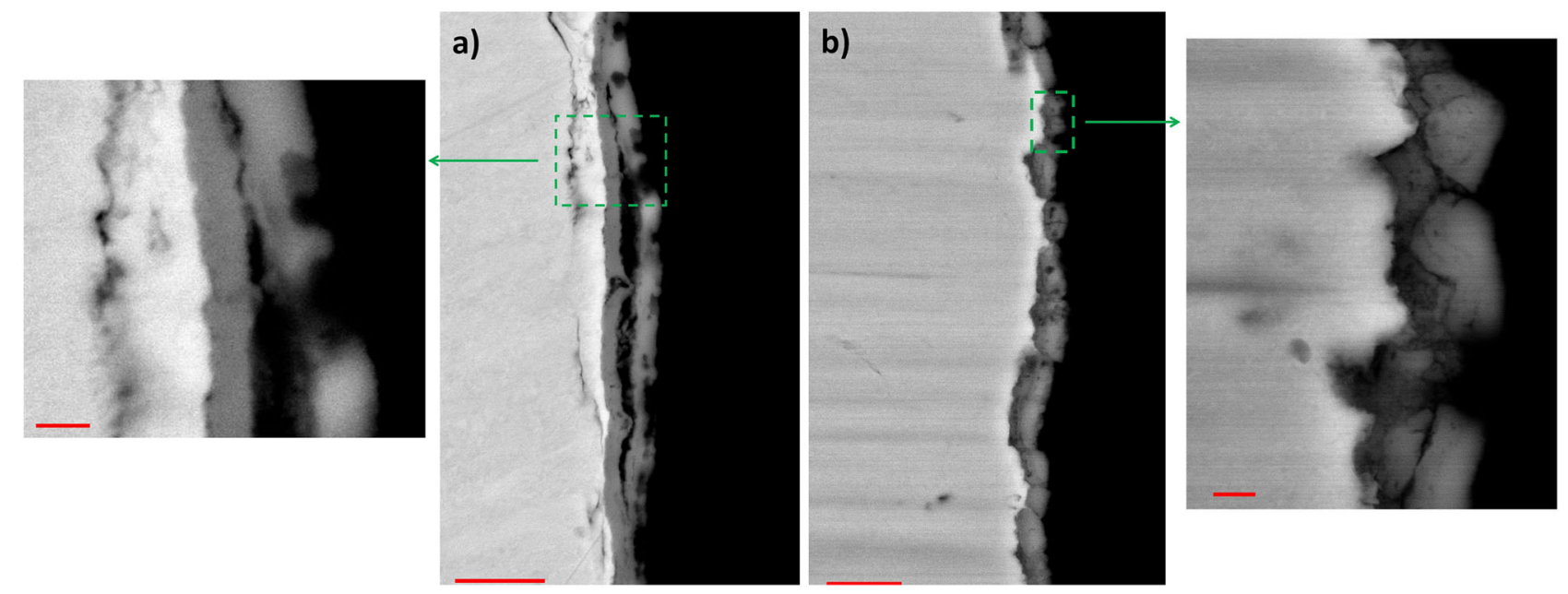

Fig. 6 SEM images of cross-sections of a carbon steel and $\mathbf{b}$ graphitized carbon steel after 125 heating-cooling cycles in the $300-500{ }^{\circ} \mathrm{C}$ temperature range. Scale bars in the main Figures are $5 \mu \mathrm{m}$. Scale bars in the insets are $1 \mu \mathrm{m}$

reduces the frictional dissipation associated with laminar flow near the walls while reducing the stress on the carbonate layer increasing its lifetime. More dynamic tests are required to further confirm this method.

\section{Molten salt and carbonate layer chemistry analysis}

In this section, we present how the proposed method of graphitization affects the molten salt and its interaction with the $\mathrm{CaCO}_{3}$ protective layer. Especially, the solubility of $\mathrm{CaCO}_{3}$ in the molten nitrate salt is a concern. In general, it is known that carbonates are soluble in molten salts. To explore this phenomenon, which directly affects the stability of this protective layer for long-term use, several tests were performed.

Firstly, the thermophysical properties (heat capacity, enthalpy of melting and melting temperature) of the salts, both before and after corrosion tests with carbon steel and graphitized carbon steel, were compared and found to be similar within the precision of equipment (Figure S13). These observations suggest that there is no significant change in the composition of the salt.

Additionally, FTIR spectra of the HitecXL salts after the corrosion tests with carbon steel and graphitized carbon steel are shown in Figure S14. It was observed that there are no changes related to the main nitrate peaks, however, the presence of traces of $\mathrm{CaCO}_{3}$ is evident in the HitecXL salt after the test with graphitized carbon steel. This observation is in favour of the limited dissolution of $\mathrm{CaCO}_{3}$ into the molten salt during the corrosion test. It should be also noted that no detectable traces of iron were present in the salts after the corrosion tests.

Finally, to further explore the stability of $\mathrm{CaCO}_{3}$ in the molten HitecXL salt under the same conditions of the corrosion test, a controlled solubility experiment was carried out. Pellets of pure $\mathrm{CaCO}_{3}$ were immersed into the molten HitecXL salt and kept at $310^{\circ} \mathrm{C}$ for 1 month. A small concentration of $\mathrm{CaCO}_{3}$ was used $(0.05 \mathrm{wt} \%)$. Next, the mixture was quenched by immersing in liquid nitrogen. In this way, the crystals of $\mathrm{CaCO}_{3}$ are easily distinguished from glassy HitecXL by SEM. The $\mathrm{CaCO}_{3}$ crystals remained in the crystalline form is the indication of their limited solubility in HitecXL. This approach was used by Su et al. to study the solubility in molten salts. ${ }^{42}$ The observation of the stability of $\mathrm{CaCO}_{3}$ micropellets in a quenched salt, (Figure S15a and S15b) as well as $\mathrm{CaCO}_{3}$ crystals (Figure S15c) are considered as an evidence of its insolubility (or very limited solubility) in the molten HitecXL salt under the test conditions. Figures S15a and S15b show the cross-section of the $\mathrm{CaCO}_{3}$ pellet in the quenched HitecXL. It is clearly observed that the pellet retains its sharp edges and does not show signs of dissolution. Separated crystals of $\mathrm{CaCO}_{3}$ have been also found in the salt and support the limited solubility in molten HitecXL salt (Figure S15c).

We consider the above-presented observations (Figures S13S15) combined with the well-formed $\mathrm{CaCO}_{3}$ layer on the surface of carbon steel (Figs. 2-6) as a good sign of the stability of $\mathrm{CaCO}_{3}$ protective layer in the molten nitrate salts. However, longer tests are required for further confirmation of the proposed method. It must be noted that limited solubility of $\mathrm{CaCO}_{3}$ can be eliminated by including minor additions of $\mathrm{CaCO}_{3}$ up to the saturation concentration i.e. Le Chatelier principle.

In this work, the mechanism of corrosion for carbon steel A516. Gr70 in molten HitecXL nitrate salt was investigated and reported. It was shown that upon direct contact of carbon steel and molten nitrate salts, two competitive reactions take place, namely oxidation (corrosion) and carbonization (protection). This finding has allowed the proposal of a simple method to improve the resistance of carbon steel to corrosion by spray graphitization. The proposed method improves the corrosion resistance of the carbon steel to molten nitrate salt under both air and inert atmospheres, in presence of humidity and under the stress of thermal cycling up to $500^{\circ} \mathrm{C}$. In particular, corrosion was not detected for graphitized carbon steel after $1500 \mathrm{~h}$ isothermal immersion tests at $310^{\circ} \mathrm{C}$ under $\mathrm{Ar}$ in the presence of humidity, while non-graphitized carbon steel demonstrated the corrosion rate of $8.8 \pm 0.6 \mu \mathrm{m} / \mathrm{year}$ under similar conditions. After the cycling immersion tests in the $300-500^{\circ} \mathrm{C}$ temperature range under air atmosphere, the corrosion rate of graphitized carbon steel was found to be almost three times lower than non-graphitized one $(11.4 \pm 1.2$ against $31.5 \pm$ $1.6 \mu \mathrm{m} / \mathrm{year}$ ). Further corrosion tests under dynamic (flow) conditions are required to confirm the proposed method for practical use or to set points for its improvement. Particularly the complete coverage of the protected surface is a factor to be considered to avoid localized corrosion.

\section{METHODS}

\section{Materials preparation}

Salts preparation. HitecXL was composed of the following mixture of nitrate salts: $15 \mathrm{wt} \%$ of $\mathrm{NaNO}_{3}, 43 \mathrm{wt} \%$ of $\mathrm{KNO}_{3}$ and $42 \mathrm{wt} \%$ of $\mathrm{Ca}\left(\mathrm{NO}_{3}\right)_{2}$. The chemical composition of the individual components can be found in Table S1. NitCal was purchased from YARA (http://www.yara.us/images/ NitCal-TDS-industrial_tcm399-66077.pdf). $\mathrm{KNO}_{3}$ and $\mathrm{NaNO}_{3}$ were purchased from SQM. From these chemicals two different HitecXL samples

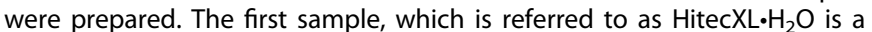
salt which has not been dried and thus maintaining the calcium nitrate 
tetrahydrate $\mathrm{Ca}\left(\mathrm{NO}_{3}\right)_{2} \cdot 4 \mathrm{H}_{2} \mathrm{O}$. This sample was used for experiments with an argon atmosphere. The second sample, which is referred to as HitecXL is a dry sample. This salt mixture (HitecXL) is melted and dried at a temperature of $200^{\circ} \mathrm{C}$ for $12 \mathrm{~h}$. This sample was used for experiments exposed to atmospheric air.

Carbon steel samples preparation. Carbon steel A516.Gr70 used in this work consisted mostly of $\mathrm{Fe}$ with small amounts of $\mathrm{C}(0.31 \mathrm{wt} \%), \mathrm{Mn}$ $(0.97 \mathrm{wt} \%)$, Si $(0.36 \mathrm{wt} \%)$ and $\mathrm{P}(0.04 \mathrm{wt} \%)$. The coupons of carbon steel were cut to the size of $(20 \mathrm{~mm} \times 10 \mathrm{~mm} \times 3 \mathrm{~mm})$ then successively washed in acetone, ethanol and water using an ultrasonic bath prior to the corrosion tests. The initial state of the carbon steel surface has a strong effect on its corrosion behaviour. ${ }^{20}$ Therefore, the samples were not polished before the corrosion tests. Polishing removes the naturally occurring oxide layer including the carbon-rich layer. This initial state would not be comparable to the real industrial conditions.

In this work, several methods of preparing the protective carbonate layer were explored:

1. Graphite in the form of powder (from Sigma-Aldrich) was added to the salt upon its preparation. Two concentrations of $1 \mathrm{wt} \%$ and $2 \mathrm{wt}$ $\%$ were investigated.

2. Graphite was sprayed, by using graphite 33 spray from Kontakt Chemie, over the clean surfaces of carbon steel pieces prior to the corrosion tests. The weights of the sample before and after the spraying were compared to calculate the mass of graphite deposited on the carbon steel.

3. The deposition of graphite using a graphite-ethanol solution, which was poured on the surface of carbon steel, followed by the evaporation of ethanol.

4. Samples of carbon steel were pre-treated under a $\mathrm{CO}_{2}$ atmosphere in the presence of humidity at $90^{\circ} \mathrm{C}$ for $12 \mathrm{~h}$ aiming to form an iron carbonate layer on the surface of the material. For that method, samples of carbon steel were placed into an alumina crucible along with $0.5 \mathrm{~g}$ of water to intensify the reaction of iron carbonate formation. Later, the crucible was placed inside a hermetic highpressure reactor (BR-300, Berghof) controlling the temperature and pressure. The reactor was purged with $\mathrm{CO}_{2}$ for $1 \mathrm{~h}$, pressurised to 2 bar and then hermetically sealed by high-pressure valves. The temperature was increased to $90^{\circ} \mathrm{C}$ and held for $12 \mathrm{~h}$.

\section{Corrosion tests protocol}

Isothermal corrosion tests. The scheme for the preparation of the isothermal corrosion tests is presented in Figure S1. All the samples were prepared in a glove box under an argon atmosphere to avoid the presence of oxygen in the reactor. A coupon of carbon steel was completely immersed in $6 \mathrm{~g}$ of HitecXL salt. The alumina crucible containing the salt and the carbon steel was covered with an alumina lid and introduced into the stainless-steel reactor. The reactor was hermetically sealed using a flexible copper ring. Then the reactor was kept inside the furnace for $1500 \mathrm{~h}$ at $310^{\circ} \mathrm{C}$. The proper sealing of the reactors was verified by comparing their weights before and after the tests.

Cycling corrosion tests. To investigate the effect of thermal cycling on the corrosion behaviour of the studied carbon steel, tests were conducted between $300-500{ }^{\circ} \mathrm{C}$ with heating/cooling rates of $2{ }^{\circ} \mathrm{C} / \mathrm{min}$. For these tests, the samples of carbon steel were completely immersed into the salt which is placed inside an alumina crucible. Then, the alumina crucible was placed inside the furnace and kept under an air atmosphere during the corrosion test. The formation of carbonates and oxidation of the metal surface are known to be competitive reactions, ${ }^{38-41}$ therefore, the presence of oxygen drives the oxidation of carbon steel and provides a more challenging condition for corrosion tests when compared to an inert atmosphere. Each experiment was conducted 3 times to confirm the results.

\section{Techniques}

Scanning electron microscopy (SEM). The surface as well as cross-sections of carbon steel samples after the corrosion tests were scanned with a Quanta 200 FEG scanning electron microscope (SEM) using a backscattered electron detector (BSED). Energy-dispersive X-ray spectroscopy (EDX) analysis was also performed. A simplified scheme of the crosssection samples preparation for SEM analysis is shown in Figure S2, which has been described and verified elsewhere. ${ }^{12,20}$ The values of corrosion layer were calculated by averaging about 200 measurements along the perimeter of the cross-section using ImageJ software.

$X$-ray diffraction (XRD). The phase composition of the carbon steel before and after the corrosion tests was identified by XRD analysis using a Bruker D8 Advance X-ray diffractometer with $\mathrm{CuKa}_{1}$ radiation $(\lambda=1.5418 \AA)$ and $\theta-2 \theta$ geometry and the EVA program from Bruker.

Optical microscope. Carl Zeiss Axio optical microscope was used to scan the surface of the samples after the corrosion tests.

Thermogravimetric analysis. Thermogravimetric analysis of each of the different salts was performed using a NETZSCH STA 449 F3 Jupiter. The measurements were conducted with constant air flow of $60 \mathrm{ml} / \mathrm{min}$ to study the thermal stability of the sample from room temperature up to $700^{\circ} \mathrm{C}$ with a heating rate of $10^{\circ} \mathrm{C} / \mathrm{min}$.

Differential scanning calorimetry (DSC). The specific heat capacity $\left(C_{p}\right)$, specific enthalpy of melting and melting temperature of the salts before and after corrosion tests were measured by DSC technique (TA instruments Q2500). A heating rate of $10^{\circ} \mathrm{C} / \mathrm{min}$ was chosen. The instrument was calibrated using sapphire as a standard material. Masses of $\sim 10 \mathrm{mg}$ of salt were placed inside a high-conductive aluminium holder sample which then was hermetically closed. The experimental error of this technique is below $3 \%$.

Fourier transform infrared spectroscopy (FTIR). To identify any degradation or contamination of the salt after the corrosion tests, the FTIR measurements were performed. Bruker Vertex 70 spectrometer equipped with diamond ATR and DLaTGS detector was used. The spectra were collected in the range of $4000-450 \mathrm{~cm}^{-1}$ in transmission mode.

\section{$\mathrm{CaCO}_{3}$ solubility test}

Solubility tests were performed to determine the stability of the protective $\mathrm{CaCO}_{3}$ layer in molten HitecXL salt. First, pellets of as-received pure $\mathrm{CaCO}_{3}$ powder were prepared by using the hydraulic press and $10 \mathrm{~mm}$ die with a maximum load of 1 ton. Then, the indicated pellets were immersed in molten HitecXL salt and the temperature was raised to $310^{\circ} \mathrm{C}$ and held for 1 month. Then, the mixture was quenched by immersion in liquid nitrogen. Quenching produced a glassy form of HitecXL and with possible dissolved $\mathrm{CaCO}_{3}$, while undissolved $\mathrm{CaCO}_{3}$ remains in a crystalline form. The stability of $\mathrm{CaCO}_{3}$ pellets was examined by SEM. The concentration of $\mathrm{CaCO}_{3}$ was $0.05 \mathrm{wt} \%$

\section{DATA AVAILABILITY}

The datasets generated during and/or analysed during the current study are available from the corresponding author on reasonable request.

\section{ACKNOWLEDGEMENTS}

The authors express their sincere thanks to Yagmur Polat and Cristina Luengo for their technical support. The help of Julien Piquot with samples preparation is also highly appreciated. We thank Dr Alexander Lowe for his useful suggestions regarding the revision of the article. The authors acknowledge the financial support from the European Commission through the $\mathrm{H} 2020$ program under Grant agreement number 657690.

\section{AUTHOR CONTRIBUTIONS}

Y.G. and A.F. designed research; Y.G., U.N. and A.Z. performed research; all authors analysed data. Y.G. wrote the paper. All authors contributed to writing the paper.

\section{ADDITIONAL INFORMATION}

Supplementary information accompanies the paper on the npj Materials Degradation website (https://doi.org/10.1038/s41529-018-0055-0).

Competing interests: The authors declare no competing interests.

Publisher's note: Springer Nature remains neutral with regard to jurisdictional claims in published maps and institutional affiliations. 


\section{REFERENCES}

1. Vignarooban, K., Xu, X., Arvay, A., Hsu, K. \& Kannan, A. M. Heat transfer fluids for concentrating solar power systems - a review. Appl. Energy 146, 383-396 (2015).

2. Gil, A. et al. State of the art on high temperature thermal energy storage for power generation. Part 1 -Concepts, materials and modellization. Renew. Sustain. Energy Rev. 14, 31-55 (2010).

3. Zhang, H., Baeyens, J., Cáceres, G., Degrève, J. \& Lv, Y. Thermal energy storage: recent developments and practical aspects. Prog. Energy Combust. Sci. 53, 1-40 (2016).

4. Liu, M. et al. Review on concentrating solar power plants and new developments in high temperature thermal energy storage technologies. Renew. Sustain. Energy Rev. 53, 1411-1432 (2016).

5. Mahlia, T. M. I., Saktisahdan, T. J., Jannifar, A., Hasan, M. H. \& Matseelar, H. S. C. A review of available methods and development on energy storage; technology update. Renew. Sustain. Energy Rev. 33, 532-545 (2014).

6. Kuravi, S., Trahan, J., Goswami, D. Y., Rahman, M. M. \& Stefanakos, E. K. Thermal energy storage technologies and systems for concentrating solar power plants. Prog. Energ. Combust. 39, 285-319 (2013).

7. Burgaleta, J. I., Arias, S. \& Ramirez, D. Gemasolar, the first tower thermosolar commercial plant with molten salt storage. SolarPACES 2011, 20-23 (2011).

8. Relloso, S. \& Delgado E. B. Experience with molten salt thermal storage in a commercial parabolic trough plant. Andasol-1 commissioning and operation. In Proc. 15th SolarPACES Symposium. 14-18 (2009).

9. Bonk, A., Sau, S., Uranga, N., Hernaiz, M. \& Bauer, T. Advanced heat transfer fluids for direct molten salt line-focusing CSPplants. Prog. Energ. Combust. 67, 69-87 (2018).

10. Maccari, A. et al. Archimede solar energy molten salt parabolic trough demo plant: a step ahead towards the new frontiers of CSP. Energy Procedia 69, 1643-1651 (2015).

11. Gomez-Vidal, J. C. Corrosion resistance of MCrAIX coatings in a molten chloride for thermal storage in concentrating solar power applications. npj Mater. Degrad. 1, 7 (2017).

12. Grosu, Y., Udayashankar, N., Bondarchuk, O., González-Fernández, L. \& Faik, A. Unexpected effect of nanoparticles doping on the corrosivity of molten nitrate salt for thermal energy storage. Sol. Energy Mater. Sol. Cells 178, 91-97 (2018).

13. Slusser, J., Titcomb, J., Heffelfinger, M. \& Dunbobbin, B. Corrosion in molten nitrate-nitrite salts. JOM 37, 24-27 (1985).

14. Fernández, A. G., Galleguillos, H., Fuentealba, E. \& Pérez, F. J. Corrosion of stainless steels and low-Cr steel in molten $\mathrm{Ca}$ (NO3)2-NaNO3-KNO3 eutectic salt for direct energy storage in CSP plants. Sol. Energy Mater. Sol. Cells 141, 7-13 (2015).

15. Ruiz-Cabañas, F. J. et al. Corrosion testing device for in-situ corrosion characterization in operational molten salts storage tanks: A516 Gr70 carbon steel performance under molten salts exposure. Sol. Energy Mater. Sol. Cells 157, 383-392 (2016).

16. Federsel, K., Wortmann, J. \& Ladenberger, M. High-temperature and corrosion behavior of nitrate nitrite molten salt mixtures regarding their application in concentrating solar power plants. Energy Procedia 69, 618-625 (2015).

17. Cheng, W. J., Ding-Jhih, C. \& Chaur-Jeng, W. High-temperature corrosion of $\mathrm{Cr}-\mathrm{Mo}$ steel in molten LiNO3-NaNO3-KNO3 eutectic salt for thermal energy storage. Sol. Energy Mater. Sol. Cells 132, 563-569 (2015).

18. Goods, S. \& Bradshaw, R. Corrosion of stainless steels and carbon steel by molten mixtures of commercial nitrate salts. J. Mater. Eng. Perform. 13, 78-87 (2004).

19. Kruizenga, A. M., Gill, D. D., Laford, M., McConohy, G. Corrosion of high temperature alloys in solar salt at 400,500 and 680 C. SANDIA National Laboratories report. Sand 2013-8256 (2013).

20. Grosu, Y., Bondarchuk, O. \& Faik, A. The effect of humidity, impurities and initial state on the corrosion of carbon and stainless steels in molten HitecXL salt for CSP application. Sol. Energy Mater. Sol. Cells 174, 34-41 (2018).

21. de Miguel, M. T., Encinas-Sánchez, V., Lasanta, M. I., García-Martín, G. \& Pérez, F. J. Corrosion resistance of $\mathrm{HR} 3 \mathrm{C}$ to a carbonate molten salt for energy storage applications in CSPplants. Sol. Energy Mater. Sol. Cells 157, 966-972 (2016).

22. Vignarooban, K., Pugazhendhi, P., Tucker, C., Gervasio, D. \& Kannan, A. M. Corrosion resistance of Hastelloys in molten metal-chloride heat-transfer fluids for concentrating solar power applications. Sol. Energy 103, 62-69 (2014).

23. Vignarooban, K. et al. Vapor pressure and corrosivity of ternary metal-chloride molten-salt based heat transfer fluids for use in concentrating solar power systems. Appl. Energy 159, 206-213 (2015).

24. Miró, L. et al. Experimental characterization of a solid industrial by-product as material for high temperature sensible thermal energy storage (TES). Appl. Energy 113, 1261-1268 (2014).
25. Dorcheh, A. S., Durham, R. N. \& Galetz, M. C. High temperature corrosion in molten solar salt: The role of chloride impurities. Mater. Corros. 9, 943-951 (2017).

26. Cabeza, L. F. et al. Immersion corrosion tests on metal-salt hydrate pairs used for latent heat storage in the 32 to $36^{\circ} \mathrm{C}$ temperature range. Mater. Corros. 52, 140-146 (2001).

27. Moreno, P. et al. Corrosion of metal and metal alloy containers in contact with phase change materials (PCM) for potential heating and cooling applications. Appl. Energy 125, 238-245 (2014).

28. Ferrer, G., Solé, A., Barreneche, C., Martorell, I. \& Cabeza, L. F. Corrosion of metal containers for use in PCM energy storage. Renew. Energy 76, 465-469 (2015).

29. Solé, A., Miró, L., Barreneche, C., Martorell, I. \& Cabeza, L. F. Corrosion of metals and salt hydrates used for thermochemical energy storage. Renew. Energy 75, 519-523 (2015).

30. Sole, A., Barreneche, C., Martorell, I. \& Cabeza, L. F. Corrosion evaluation and prevention of reactor materials to contain thermochemical material for thermal energy storage. Appl. Therm. Eng. 94, 355-363 (2016).

31. Sarvghad, M., Steinberg, T. A., \& Will, G. Corrosion of stainless steel 316 in eutectic molten salts for thermal energy storage. Solar Energy. In Press, 2018. https://doi. org/10.1016/j.solener.2018.03.053

32. Szymański, K., Hernas, A., Moskal, G. \& Myalska, H. Thermally sprayed coatings resistant to erosion and corrosion for power plant boilers-a review. Surf. Coat. Tech. 268, 153-164 (2015).

33. Hassani-Gangaraj, S. M., Moridi, A. \& Guagliano, M. Critical review of corrosion protection by cold spray coatings. Surf. Eng. 31, 803-815 (2015).

34. Dorcheh, A. S. \& Galetz, M. C. Slurry aluminizing: a solution for molten nitrate salt corrosion in concentrated solar power plants. Sol. Energy Mater. Sol. Cells 146, 8-15 (2016).

35. Loghman-Estarki, M. R. et al. Evaluation of hot corrosion behavior of plasma sprayed scandia and yttria co-stabilized nanostructured thermal barrier coatings in the presence of molten sulfate and vanadate salt. J. Eur. Ceram. Soc. 35, 693-702 (2015).

36. Liu, S., Liu, Z., Wang, Y. \& Tang, J. A comparative study on the high temperature corrosion of TP347H stainless steel, C22 alloy and laser-cladding C22 coating in molten chloride salts. Corros. Sci. 83, 396-408 (2014).

37. Agüero, A., Audigié, P., Rodríguez, S. \& Encinas-Sánchez, V. Protective coatings for high temperature molten salt heat storage systems. in solar concentration powerplants. SOLARPACES 2017. 1-8 (2017).

38. Dugstad., A. Fundamental aspects of $\mathrm{CO} 2$ metal loss corrosion, part 1: mechanism. NACECorrosion 2006. 1-18 (2006).

39. Dugstad, A., Hemmer, H. \& Seiersten, M. Effect of steel microstructure on corrosion rate and protective iron carbonate film formation. Corrosion 57, 369-378 (2001).

40. Choi, Y. S., Nesic, S. \& Young, D. Effect of impurities on the corrosion behavior of $\mathrm{CO}_{2}$ transmission pipeline steel in supercritical $\mathrm{CO} 2$-water environments. Environ. Sci. Technol. 44, 9233-9238 (2010).

41. Kermani, M. B. \& Morshed, A. Carbon dioxide corrosion in oil and gas productionA compendium. Corrosion 59, 659-683 (2003).

42. Su, S., Villalon, T., Pal, U., Powell, A. Techniques for measuring solubility and electrical conductivity in molten salts. Advances in Molten Slags, Fluxes, and Salts: Proceedings of the 10th International Conference on Molten Slags, Fluxes and Salts. 465-475, (2016).

Open Access This article is licensed under a Creative Commons Attribution 4.0 International License, which permits use, sharing, adaptation, distribution and reproduction in any medium or format, as long as you give appropriate credit to the original author(s) and the source, provide a link to the Creative Commons license, and indicate if changes were made. The images or other third party material in this article are included in the article's Creative Commons license, unless indicated otherwise in a credit line to the material. If material is not included in the article's Creative Commons license and your intended use is not permitted by statutory regulation or exceeds the permitted use, you will need to obtain permission directly from the copyright holder. To view a copy of this license, visit http://creativecommons. org/licenses/by/4.0/.

(c) The Author(s) 2018 